\title{
Cardiac interventional procedures in the United Kingdom during 1991
}

\author{
Peter J B Hubner on behalf of the British Cardiovascular Intervention Society
}

Council of the British Cardiovascular Intervention Society P J B Hubner R Balcon

J Dyet

D Dymond

H Gray

A Harley

A Mackintosh

P Quigley

$M$ Rees

M Rothman

T Shaw

M Shiu

Correspondence to:

Dr P J B Hubner, Groby LE3 9QE.

Accepted for publication 6 April 1993 Road Hospital, Leicester The British Cardiovascular Intervention
Society asked all cardiac units that performed
adult and paediatric interventional proce-
dures for information on the procedures that
had been performed between 1 January and
31 December 1991 . This was the fourth year
of the survey. Records were obtained from 52
adult and 20 paediatric units. The units were
unchanged from those of 1990 . The Royal
Free Hospital started performing angioplasty
without on site surgery and also continued
procedures at neighbouring hospitals with on
site cardiac surgery. Hence the number of
units rose from 51 to 52 in 1991 .

There were 20 paediatric cardiology units, with new units recording procedures at Cardiff and Manchester Royal Infirmary. The Royal Free Hospital, Northern General Hospital Sheffield, and St Thomas's Hospital did not perform paediatric procedures. The remaining hospitals were the same as recorded in the 1990 report.

This report should be read in conjunction with the $1988-1990$ reports. ${ }^{1-3}$

\section{Percutaneous transluminal coronary angioplasty (PTCA) \\ NUMBER OF PROCEDURES \\ There were 9933 procedures recorded (174 per million of the population). The rate of increase over the previous year of $17 \%$ was similar to that of 1990 (18\%). Table $1 \mathrm{com}$ - pares the figures from the United Kingdom with those of other countries. In $199112 \%$ of the total PTCA procedures were performed in private hospitals. Table 2 summarises the}

Table 1 Percutaneous transluminal coronary angioplasty in western European countries and the United States 1985-1991

\begin{tabular}{|c|c|c|c|c|c|}
\hline \multirow[b]{2}{*}{ Country } & \multirow[b]{2}{*}{ Population (millions) } & \multicolumn{4}{|c|}{ No/million population } \\
\hline & & 1985 & 1987 & 1989 & 1991 \\
\hline $\begin{array}{l}\text { Austria } \\
\text { Belgium } \\
\text { Denmark } \\
\text { Finland } \\
\text { France } \\
\text { Germany } \\
\text { Italy } \\
\text { Netherlands } \\
\text { Norway } \\
\text { Portugal } \\
\text { Spain } \\
\text { Sweden } \\
\text { Switzerland } \\
\text { United Kingdom } \\
\text { USA }\end{array}$ & $\begin{array}{c}7 \cdot 5 \\
10 \\
5 \\
5 \\
55 \\
61 \\
55 \\
14 \cdot 5 \\
4 \\
10 \\
39 \\
8 \cdot 5 \\
6 \cdot 5 \\
57 \\
250\end{array}$ & $\begin{array}{r}66 \\
111 \\
5 \\
9 \\
81 \\
108 \\
9 \\
186 \\
10 \\
3 \\
23 \\
20 \\
53 \\
26 \\
456\end{array}$ & $\begin{array}{r}134 \\
263 \\
21 \\
42 \\
143 \\
197 \\
25 \\
324 \\
46 \\
7 \\
\star \\
55 \\
123 \\
73 \\
750\end{array}$ & $\begin{array}{r}260 \\
412 \\
43 \\
90 \\
338 \\
384 \\
64 \\
466 \\
134 \\
19 \\
87 \\
141 \\
304 \\
126 \\
1000\end{array}$ & $\begin{array}{r}421 \\
716 \\
103 \\
173 \\
555 \\
532 \\
100 \\
614 \\
300 \\
52 \\
139 \\
215 \\
411 \\
174 \\
1300\end{array}$ \\
\hline
\end{tabular}

*Data not available.

(Source Van den Brand ${ }^{4}$ ) workload of all cardiac units. Information on numbers of cardiac catheterisations and PTCAs was available from 47 of these cardiac units. At these units there were 68096 adult cardiac catheterisations for coronary, valvar, and other heart disease and 8819 PTCAs. The proportion of PTCAs to cardiac catheterisations was $12 \%$ (range 3-38\%). Some cardiac units had additional patients referred for PTCA who had cardiac catheterisation performed elsewhere, usually where there was no on site cardiac surgery.

\section{RESULTS OF PTCA}

Some units, especially the private hospitals, provided only limited information. The results in this survey and its tables show the number of cardiac units and the number of procedures from which the information was derived.

The overall results of coronary angioplasty and the results from single vessel dilatation and from multivessel dilatation in 1991 are shown in tables 3-5. PTCA mortality fell from $0.71 \%$ in 1990 to $0.48 \%$ in 1991 . This includes nine deaths in 184 PTCAs for acute myocardial infarction. For PTCA outside the setting of acute myocardial infarction the mean mortality in 1991 was $0.37 \%$. The mortality for multivessel dilatation has progressively fallen from $1.6 \%$ in 1988 , to $1.3 \%$ in 1989 , to $1.1 \%$ in 1990 , and to $0.52 \%$ in 1991. The emergency coronary artery bypass rate for single vessel dilatation rose from $2.0 \%$ to $2 \cdot 6 \%$. As in $1990,83 \%$ of PTCAs were for single vessel dilatation.

CLINICAL INDICATIONS FOR PTCA (TABLE 6)

The results were similar to those of 1990 . The definitions of unstable angina, postthrombolysis, and acute myocardial infarction are those given in the 1989 report. $^{2}$

\section{OTHER CORONARY INTERVENTIONAL} PROCEDURES (TABLE 7)

These 191 procedures represent only $2 \%$ of the total angioplasties performed. Elective or bail-out stenting was the commonest of these procedures.

SURGICAL COVER FOR PTCA (TABLE 8) In 1989 and 1990 the mortality for PTCA at cardiac units without surgery on site was the same or less than those units with surgical facilities. In 1991 the mortality was $1 \cdot 1 \%$ and $0.43 \%$ for units with surgery off-site and on- 
Table 2 Percutaneous transluminal coronary angioplasty in the United Kingdom: number of procedures per annum in 52 cardiac units

\begin{tabular}{cl}
\hline Procedures & Units \\
\hline $0-50$ & 6 \\
$51-100$ & 9 \\
$101-150$ & 7 \\
$151-200$ & 7 \\
$201-250$ & 6 \\
$251-300$ & 8 \\
$301-350$ & 3 \\
$351-400$ & 3 \\
$401-450$ & 2 \\
$501-550$ & 1 \\
\hline
\end{tabular}

Table 4 Percutaneous transluminal coronary angioplasty in the United Kingdom during 1991: single vessel dilatation

\begin{tabular}{lccc}
\hline & Data from & $\%$ & Range(\%) \\
\hline $\begin{array}{l}\text { Cardiac units } \\
\text { \% of total percutaneous }\end{array}$ & 46 & & \\
$\quad \begin{array}{l}\text { transluminal coronary } \\
\text { angioplasties }\end{array}$ & 6861 & 83 & $61-100$ \\
$\begin{array}{l}\text { Mortality } \\
\text { Emergency coronary }\end{array}$ & 6778 & $0 \cdot 43$ & $0-2 \cdot 1$ \\
$\quad \begin{array}{l}\text { artery bypass grafting } \\
\text { Myocardial infarction }\end{array}$ & 6778 & $2 \cdot 6$ & $0-10$ \\
Success & 6503 & $1 \cdot 4$ & $0-20$ \\
\hline
\end{tabular}

Table 5 Percutaneous transluminal coronary angioplasty in the United Kingdom during 1991: multiple vessel dilatation

\begin{tabular}{lccc}
\hline & Data from & $\%$ & Range(\%) \\
\hline $\begin{array}{l}\text { Cardiac units } \\
\text { \% of total percutaneous }\end{array}$ & 45 & & \\
$\begin{array}{l}\quad \text { transluminal coronary } \\
\text { angioplasties }\end{array}$ & 1360 & 17 & $2-35$ \\
$\begin{array}{l}\text { Number of vessels } \\
\text { Mortality }\end{array}$ & 1344 & $0 \cdot 52$ & $0-7 \cdot 4$ \\
Emergency coronary & & & $2 \cdot 2$ \\
$\quad \begin{array}{l}\text { artery bypass grafting } \\
\text { Myocardial infarction }\end{array}$ & 1344 & $2 \cdot 2$ & $0-16$ \\
Success & 1261 & $1 \cdot 6$ & $0-17$ \\
\hline
\end{tabular}

Table 6 Percutaneous transluminal coronary angioplasty in the United Kingdom in 1991: clinical indications

\begin{tabular}{|c|c|c|c|c|c|c|}
\hline & $\begin{array}{l}\text { Unstable } \\
\text { angina }\end{array}$ & $\begin{array}{l}\text { Post } \\
\text { thrombolysis }\end{array}$ & $\begin{array}{l}\text { Acute } \\
\text { myocardial } \\
\text { infarction }\end{array}$ & $\begin{array}{l}\text { Repeat } \\
\text { percutaneous } \\
\text { transluminal } \\
\text { coronary } \\
\text { angioplasty }\end{array}$ & $\begin{array}{l}\text { Chronic } \\
\text { occlusion }\end{array}$ & $\begin{array}{l}\text { Previous } \\
\text { coronary } \\
\text { artery } \\
\text { grafting }\end{array}$ \\
\hline $\begin{array}{l}\text { Cardiac units } \\
\text { Total procedures } \\
\text { Mortality }(\%)\end{array}$ & $\begin{array}{c}38 \\
1738 \\
0 \cdot 7\end{array}$ & $\begin{array}{c}32 \\
474 \\
1 \cdot 3\end{array}$ & $\begin{array}{c}23 \\
184 \\
4 \cdot 9\end{array}$ & $\begin{array}{c}42 \\
1059 \\
0.01\end{array}$ & $\begin{array}{l}36 \\
727 \\
0 \cdot 15\end{array}$ & $\begin{array}{l}43 \\
706 \\
0.46\end{array}$ \\
\hline $\begin{array}{l}\text { Emergency coronary } \\
\text { artery bypass grafting(\%) } \\
\text { Myocardial infarction(\%) } \\
\text { Success }(\%)\end{array}$ & $\begin{array}{r}3 \cdot 3 \\
2 \cdot 5 \\
88\end{array}$ & $\begin{array}{r}1 \cdot 8 \\
2 \cdot 9 \\
88\end{array}$ & $\begin{array}{c}6 \cdot 2 \\
6 \cdot 0 \\
79\end{array}$ & $\begin{array}{r}1 \cdot 9 \\
1 \cdot 0 \\
89\end{array}$ & $\begin{array}{l}2 \cdot 7 \\
1 \cdot 6 \\
53\end{array}$ & $\begin{array}{l}0 \cdot 31 \\
0 \cdot 79 \\
85\end{array}$ \\
\hline
\end{tabular}

Table 7 Other coronary interventional procedures in the United Kingdom during 1991

\begin{tabular}{lllllll}
\hline & & & & \multicolumn{3}{c}{$\begin{array}{l}\text { Emergency } \\
\text { coronary } \\
\text { artery }\end{array}$} \\
& $\begin{array}{l}\text { Cardiac } \\
\text { units }\end{array}$ & $\begin{array}{l}\text { No of } \\
\text { procedures }\end{array}$ & Success & $\begin{array}{l}\text { Myocardial } \\
\text { infarction }\end{array}$ & $\begin{array}{l}\text { byafting } \\
\text { grass }\end{array}$ & Death \\
\hline Directional atherectomy & 14 & 34 & 30 & 1 & 2 & 1 \\
Stent (elective) & 9 & 40 & 36 & 0 & 1 & 0 \\
Stent (bail-out) & 8 & 41 & 38 & 4 & 1 & 0 \\
Drill & 5 & 19 & 8 & 0 & 2 & 0 \\
Excimer laser & 3 & 51 & 39 & 2 & 1 & 3 \\
Embolisation & 4 & 6 & 5 & 0 & 0 & 0 \\
\hline
\end{tabular}

Table 8 Percutaneous transluminal coronary angioplasty in the United Kingdom in 1991: comparison between cardiac units with on site and off site surgery

\begin{tabular}{lcc}
\hline & On site & Off site \\
\hline Cardiac units & 45 & 7 \\
Numbers & 9192 & 741 \\
Mortality & $36 / 8330$ & $8 / 741$ \\
& $(0 \cdot 43 \%)$ & $(1 \cdot 1 \%)$ \\
Emergency coronary & $225 / 8455$ & $11 / 741$ \\
artery bypass grafting & $(2 \cdot 7 \%)$ & $(1 \cdot 5 \%)$ \\
Myocardial & $114 / 7429$ & $16 / 741$ \\
infarction & $(1 \cdot 5 \%)$ & $(2 \cdot 2)$ \\
\hline
\end{tabular}

site respectively. The lower use of emergency coronary artery bypass surgery by off-site units was unchanged from 1989 and 1990 surveys.

Balloon dilatation of values in adults and other procedures (table 9)

The frequency of balloon dilatation of the aortic valve had again halved over the previous year and the number of procedures was small (total 21). Balloon dilatation of the mitral valve, which had been doubling in frequency between 1988 and 1990, levelled off from 213 procedures in 1990 to 243 in 1991. This increase reflects the use of the Inoue balloon which has simplified balloon dilatation of the mitral valve.

\section{Paediatric interventional procedures} (table 10)

Occlusion of patent ductus arteriosus again increased, rising from 159 in 1990 to 225 cases in 1991. For 1991 balloon atrial septostomy was included in the analysis. These two procedures largely accounted for the increase in total procedures from 767 in 1990 to 1069 in 1991.

Comments on the 1991 survey of procedures

The numbers of coronary angioplasties during 1991 continued to be low compared with many other countries (table 1). From 1988 to 1991 there has been no change in the need for emergency coronary artery bypass surgery which has continued at a rate of $2 \cdot 1-2 \cdot 7 \%$. For paediatric procedures, occlusion of patent ductus arteriosus had become the second commonest procedure with no mortality and low morbidity.

Table 9 Balloon dilatation of valves in adults and other procedures in the United Kingdom in 1991

\begin{tabular}{lcclc}
\hline & $\begin{array}{l}\text { Cardiac } \\
\text { units }\end{array}$ & Numbers & Death & Complications \\
\hline Pulmonary & 15 & 21 & 0 & 0 \\
Aortic & 11 & 21 & 4 & 1 \\
Mitral & 25 & 243 & 1 & 11 \\
$\begin{array}{l}\text { Coarctation of } \\
\text { aorta }\end{array}$ & 4 & 10 & 0 & 0 \\
$\begin{array}{l}\text { Retrieval of } \\
\text { foreign body }\end{array}$ & 10 & 15 & 0 & 0 \\
\hline
\end{tabular}


Table 10 Paediatric interventional procedures (total 1069) in the United Kingdom in 1991

\begin{tabular}{lccll}
\hline & Cardiac units & Number & Death & Complications \\
\hline Pulmonary valve dilatation & 20 & 252 & 0 & 4 \\
Aortic valve dilatation & 14 & 118 & 7 & 5 \\
Mitral valve dilatation & 1 & 2 & 0 & 0 \\
Coarctation of aorta & 16 & 103 & 2 & 4 \\
Occlusion of patent ductus arteriosus & 15 & 225 & 0 & 5 \\
Pulmonary artery or & & 29 & 1 & 0 \\
branch stenosis dilatation & 5 & 28 & 0 & 0 \\
Mustard conduit dilatation & 12 & 8 & 0 & 0 \\
Shunt dilatation & 4 & 41 & 0 & 0 \\
Fallot's tetralogy & 9 & 6 & 0 & 0 \\
Subaortic stenosis & 4 & 209 & 1 & 3 \\
Atrial septostomy & 15 & 4 & 0 & 0 \\
Embolisation & 9 & 4 & 0 & 0 \\
Closure of atrial septal defect & 1 & 10 & 0 & 0 \\
Closure of ventricular septal defect & 1 & & 0 \\
Stenting of ductus arteriosus & 2 & & & \\
\hline
\end{tabular}

The British Cardiovascular Intervention Society is grateful to the staff of the individual cardiac units who supplied the data requested. Mrs $M$ Tegg has devoted considerable effort and skill to collect and analyse the data of the four surveys from 1988 to 1991 . Her work is very gratefully acknowledged.

1 Hubner PJB. Cardiac interventional procedures in the United Kingdom during 1988. Br Heart $\mathcal{f} 1990 ; 64$ : United

2 Hubner PJB on behalf of the British Cardiovascular Intervention Society. Cardiac interventional procedures in the United Kingdom in 1989. Br Heart $f$ 1991;66: 469-71.

3 Hubner PJB on behalf of the British Cardiovascular Intervention Society. Cardiac interventional procedures in the United Kingdom in 1990. Br Heart $\mathcal{F} 1992 ; 68$ : 434-6.

4 Van den Brand $M$ and the European Angioplasty Survey Group Utilization of coronary angioplasty and cost of angioplasty disposables in 14 western European countries. Eur Heart $\mathcal{F}$ 1993;14:391-7.

\section{BRITISH CARDIAC SOCIETY NEWSLETTER}

\section{Annual Meeting 1993}

The 1993 Annual Meeting of the British Cardiac Society was held at the Wembley Conference Centre from 18 to 21 May. Approximately 1500 delegates attended, and the number of abstracts submitted and accepted was greater than in previous years. There were several innovations including the integration of the affiliated groups into the main part of the meeting, a moderated poster session and, to give the delegates more time to visit the exhibition, the business meeting of the Society was moved from its traditional position on Thursday lunchtime to Wednesday evening. Members' comments on the meeting are encouraged. Please write to Duncan Dymond.

The Young Investigators Award attracted a record number of submissions and we thank Professor Michael Davies, Professor Remme, Professor S Cobbe, and Dr P Weissberg for judging the competition. The standards of the presentations were very high and the judges awarded a joint first prize to Dr A Brady of the National Heart and Lung Institute, London, for a submission entitled "Nitric oxide and cardiac myocyte contraction" and to $\mathrm{Dr} M$ Bennett, from the University of Wales College of Medicine, for a submission entitled "Central role of the c-myc proto-oncogene in vascular smooth muscle cell proliferation and cell death".

The Wembley Conference Centre has always had certain disadvantages but it is the only suitable centre in London. There are no immediate plans to hold future meetings in London, and whether or not we do so will depend on finding an adequate alternative conference facility at reasonable cost. Next year's Annual Meeting is in Torquay from 17 May to 20 May.

\section{Queen's birthday honours 1993}

We offer warmest congratulations to Desmond Julian and George Radda who were both awarded the CBE. Their major contributions to cardiology have been appropriately recognised. It was also a pleasure to see the award of an OBE to Dr James Read, Director of the National Centre for Coding and Classification, with whom the British Cardiac Society is working at present on data management.

European Society of Cardiology

Philip Poole-Wilson writes: "The Research and Training Committee of the European Society of Cardiology met recently under the chairmanship of Julius Papp. Twenty four applications were received for research fellowships and 25 for training fellowships. Five research fellowships and six training fellowships have been granted. The names of the successful applicants will be announced during the congress in Nice.

An ad hoc committee had been established by the Board of the European Society of Cardiology to consider whether a basic journal in cardiovascular science should be supported by the European Society of Cardiology. That committee has now reported and negotiations are beginning with existing journals.

Many of you will be aware that the Board of the European Society of Cardiology has initiated a European Video fournal of Cardiology (EVJC). This is a joint venture between the European Society of Cardiology, Cardio Diffusion, and Kluwer. The editor is Lars Ryden and the members of the editorial board are Marten Rosenqvist (deputy editor), Antonio Bayes de Luna, Franz Dienstl, Jean-Marie Detry, Raimund Erbel, and Gunter Breithardt. There will be six issues of the video journal each year. This is a new venture. There can be no doubt that new technologies are going to emerge in the communication of advances in cardiology and in teaching. Precisely how these will be used in the future is not yet clear.

Discussions are continuing on the establishment of a working group on heart failure within the European Society of Cardiology."

Implications for training in cardiovascular medicine of the Chief Medical Officer's report on specialist training (Calman report)

Michael Webb-Peploe, chairman of the Manpower and Training Committee, writes: "In July 1992 the Secretary of State for Health set up a working group under the chairmanship of the Chief Medical Officer to advise her on any action needed to bring the United Kingdom into line with the European Commission (EC) directives on medical training. The EC considered that the United Kingdom's position was unsatisfactory because $(a)$ in a few specific cases certificates from other member states had not been recognised as being evidence of completion of specialist training by the Royal Colleges and the General Medical Council (GMC), and (b) the United Kingdom certificate was often awarded at an intermediate point during postgraduate training rather than at its completion."

MAIN RECOMMENDATIONS OF THE REPORT "These focus largely on the length of time spent in training and the content of education and training programmes. The need to comply with EC regulations, by avoiding a second "accreditation" separate and distinct from an EC certificate of specialist training, is met by the proposal to replace accreditation by a certificate signifying completion of specialist training (CCST) which will be equivalent to the EC certificate. This certificate will be granted by the GMC on the advice of the Colleges, and the Medical Register will show the award of a CCST or the equivalent qualification from another EC member state by "CT" as a specialist indicator together with the relevant specialty, the year of award, and the member state in which the qualification was awarded.

In aiming to shorten training programmes the report expects that most trainees would be appointed to consultant career grade posts by the age of 31 or 32 years. Minimum training programmes of two years of general professional training at senior house officer level (that is, starting at full registration) followed by four to six years of higher specialist training (depending on specialty) are the minimum periods proposed by the Colleges. The establishment of a single training grade (replacing career registrar and senior registrar grades) is strongly urged by 1995 as being one way of shortening training programmes and eliminating the time-wasting hurdle between registrar and senior registrar grades.

After a minimum of two years of general professional training and passing the MRCP examination, the United Kingdom trainee would enter a six year cardiovascular 